\title{
Myasthenia Gravis in a Child with Sequelae of Opsoclonus-Myoclonus Syndrome
}

\author{
Angus A. Wilfong and Fabio Fernandez
}

\begin{abstract}
Immune-mediated myasthenia gravis occurred in a 13-month-old girl who had sequelae of an opsoclonus-myoclonus syndrome. She had an abnormal Raji cell assay along with elevated antiacetylcholine receptor and antithyroglobulin antibodies. No evidence of an associated malignancy was found with either condition. Clearly, the co-occurrence of two diseases within a single patient does not establish a common pathogenesis. Nevertheless, this is a provocative association and may point to an immunologically mediated process in the opsoclonus-myoclonus syndrome.
\end{abstract}

\begin{abstract}
RÉSUMÉ: Myasthénie grave chez un enfant avec séquelles du syndrome d'opsoclonie-myoclonie. Une myasthénie grave à médiation immunitaire est survenue chez une fille de 13 ans qui avait des séquelles d'un syndrome d'opsoclonie-myoclonie. Elle présentait un test de cellules Raji anormal de même que des niveaux élevés d'anticorps antirécepteurs de l'acétylcholine et antithyroglobuline. On n'a mis en évidence aucune néoplasie maligne associée à ces affections. Deux maladies peuvent survenir chez un même patients sans que ce fait n'établisse qu'elles ont une pathogenèse commune. Cependant, il s'agit ici d'une association intrigante et peut indiquer un processus à médiation immunologique dans le syndrome d'opsoclonie-myoclonie.
\end{abstract}

Can. J. Neurol. Sci. 1992; 19:88-89

Orzechowski' coined the term 'opsoclonus' in 1927 to characterize unusual eye movements observed in a number of patients with non-epidemic encephalitis. However, Kinsbourne's ${ }^{2} 1962$ description of six infants significantly escalated recognition and understanding of the syndrome whose typical features are periodic, jerking, ataxic, conjugate eye movements occurring in all planes, often described as 'chaotic', in addition to axial myoclonus, and cerebellar ataxia. ${ }^{3}$ The course is often protracted and recovery variable. It most frequently occurs in infancy or childhood, but adult-onset cases are well described. ${ }^{4}$

The underlying pathophysiology of the opsoclonusmyoclonus syndrome has yet to be fully elucidated. Some investigators support an immunological basis, while others postulate the presence of neurotoxic substances liberated by an associated occult neoplasm or neurological dysfunction caused by an unidentified agent, such as a virus. ${ }^{2,3,5-8}$

The pathophysiology of myasthenia gravis, however, is considerably better understood. This is a disorder characterized by development of autoantibodies against postsynaptic nicotinic acetylcholine receptors within the neuromuscular junction..$^{9,10}$ Resultant defects in neuromuscular transmission produce the distinctive pattern of fatiguability.
The co-occurrence of myasthenia gravis with opsoclonusmyoclonus syndrome may provide insight into the pathophysiology of the latter condition by suggesting a common immunologically-mediated link.

\section{Clinical Report}

A previously normal 13 -month-old girl experienced sudden onset of an encephalopathic illness associated with chaotic eye movements and severe ataxia consistent with the opsoclonus-myoclonus syndrome. Routine hematological and cerebrospinal fluid analyses did not reveal evidence of an infectious disease. Appropriate radiographic and biochemical studies were performed to exclude the presence of an occult neural crest tumor. Marked developmental regression ensued with loss of speech and ability to walk. She was treated with Prednisone from 1976 through 1985 . This resulted in some short-term symptomatic improvement; however, the patient was left with significant neurological sequelae. She did not walk again until 4 years of age and persisted in being somewhat ataxic. In addition, she had mild mental retardation, tremor, and nystagmus.

The patient's neurological deficits remained static until the age of $13^{1 / 2}$ years when right-sided ptosis, dysphagia, dysarthria, and generalized weakness developed. Her symptoms would typically fluctuate over the course of a day due to fatigability. Physical examination revealed a cachectic-appearing adolescent in mild respiratory distress. Mild mental retardation was evident. A minimal right-sided ptosis was present, as was end-point nystagmus in all directions, myopathic facies, severe

From the Departments of Pediatrics and Neurology, Baylor College of Medicine, Houston, Texas

Received June 5, 1991. Accepted in final form October 10, 1991

Reprint requests to: Angus A. Wilfong, Section of Pediatric Neurology, Room R-618, Texas Children's Hospital, 6621 Fannin, Houston, Texas, U.S.A. 77030 
palatal incompetence with dysarthria, pooling of oral secretions, and a trigrooved tongue pattern. There was marked generalized muscle wasting, especially about the shoulder girdle. Muscle strength was mildly reduced proximally with prominent fatiguability. Deep tendon reflexes were normal and plantar responses were flexor. Mild limb dysmetria and gait ataxia were evident. No sensory deficits were detected.

Laboratory studies revealed normal blood counts, thyroid and liver function tests, and serum creatine kinase and aldolase. Erythrocyte sedimentation rate (ESR) was elevated at $44 \mathrm{~mm} / \mathrm{hr}$ (normal $0-20$ ). Antinuclear antibody, rheumatoid factor, and rapid plasma reagin (RPR) assays were negative. Magnetic resonance imaging of the brain was within normal limits. Electromyographic needle exam and nerve conduction studies were normal; however, repetitive nerve stimulation at 2 $\mathrm{Hz}$ demonstrated a $62 \%$ decremental response in the paranasalis muscles.

The diagnosis of myasthenia gravis was further supported by antiacetylcholine receptor antibody levels of $32.0 \mathrm{nmol} / \mathrm{L}$ (normal less than 0.5 ). Antithyroglobulin antibody titres were also elevated at 1:650 (normal less than 1:100), but antimicrosomal antibody titres were normal. Computed axial tomographic scanning of the thorax revealed a normal thymus gland.

Additional immunological studies performed included normal serum quantitative immunoglobulins, normal $\mathrm{Clq}$ binding, and normal lymphocyte monoclonal phenotyping and mitogen proliferative responses. The Raji cell assay was abnormal at $253 \mu \mathrm{g}$ Aggregated Human Gamma Globulin (AHG) EQ/mL (normal < 50 AHG EQ/mL).

Initiation of pyridostigmine bromide (Mestinon) therapy resulted in dramatic improvement in strength, bulbar function, and respiratory status. Three months later a trans-sternal thymectomy was performed. Histopathological examination revealed thymic follicular hyperplasia.

\section{Discussion}

A number of theories have been advanced over the years in attempts to explain the pathophysiology of the opsoclonusmyoclonus syndrome. Kinsbourne ${ }^{2}$ had suggested that some form of autoimmune process may be at work, triggered in response to a nonspecific stimulus such as a virus or immunization. He astutely noted the beneficial effect of immunosuppressive therapy with $\mathrm{ACTH}$, as well as disease relapse after its withdrawal. Dropcho 7 reviewed current evidence supporting an autoimmune basis for neuroblastoma-associated opsoclonusmyoclonus syndrome. As he points out, a high proportion of neuroblastomas associated with opsoclonus-myoclonus syndrome show differentiation towards the more benign ganglioneuromas. In addition, the occurrence of opsoclonusmyoclonus carries a good prognosis for survival that is independent of the patient's age, site of tumor, and tumor stage. Thus, it has been theorized that an antineuroblastoma immune response may cause tumor regression, as well as leading to development of the opsoclonus-myoclonus syndrome by crossreacting to central nervous system (CNS) antigens. Further indirect evidence supporting an immunological basis for the condition includes elevated cerebrospinal fluid immunoglobulins, macrophage inhibition by neuroblastoma antigens, antineurofilament antibodies, and circulating anti-CNS antibodies in afflicted patients. ${ }^{5,8}$

The patient described herein had indicators of immunological dysfunction commonly associated with myasthenia gravis, namely positive antiacetylcholine and antithyroglobulin antibodies. However, she had other indicators rarely associated with myasthenia gravis such as the elevated ESR and abnormal Raji cell assay. These latter findings might suggest an underlying dysimmune process that was responsible for not only the myasthenia gravis, but also the earlier opsoclonus-myoclonus. Clearly, the co-occurrence of two diseases within a single patient does not establish a common underlying pathogenesis and their association may simply be coincidental. Nevertheless, this is a provocative association, and may point to an immunologically mediated process in the opsoclonus-myoclonus syndrome.

\section{REFERENCES}

1. Orzechowski K. De l'ataxie dysmetrique des yeux: remarques sur l'ataxie des yeux myoclonique (Opsoclonie, Opsochorie). J Psychol Neurol 1927; 35: 1-18.

2. Kinsbourne M. Myoclonic encephalopathy of infants. J Neurol Neurosurg Psychiatry 1962; 25: 271-276.

3. Warrier RP, Kini R, Besser A, et al. Opsomyoclonus and Neuroblastoma. Clin Pediatr 1985; 24: 32-34.

4. Digre KB. Opsoclonus in Adults. Report of Three Cases and Review of the Literature. Arch Neurol 1986; 43: 1165-1175.

5. Dyken P, Kolar O. Dancing Eyes, Dancing Feet: Infantile Polymyoclonia. Brain 1968; 91: 305-320.

6. Bray PF, Ziter, FA, Lahey ME, et al. The Coincidence of Neuroblastoma and Acute Cerebellar Encephalopathy. J Pediatr 1969; 75: 983-990.

7. Dropcho EJ. The Remote Effects of Cancer on the Nervous System. Neurol Clin 1989; 7: 579-603.

8. Plioplys AV, Greaves A, Yoshida W. Anti-CNS Antibodies in Childhood Neurological Diseases. Neuropediatrics 1989; 20: 93 102.

9. Steinman L. Immunogenetic Mechanisms in Myasthenia Gravis. Prog Brain Res 1990; 84: 117-124.

10. Vincent A. Neuroimmunology of Myasthenia Gravis. Brain Behav Immunol 1988; 2: 346-351. 